Island Studies Journal, Vol. 1, No. 1, 2006, pp. 19-42

\title{
A Phenomenology of Islands
}

Pete Hay

School of Geography and Environmental Studies, University of Tasmania,

Tasmania, Australia

Peter.Hay@utas.edu.au

\begin{abstract}
The question is posed: is a coherent theory of islandness - nissology - possible? Faultlines within constructions of islands and islandness are noted. Some of these axes of contestation have remained latent but have the potential to be sharply divisive. Three of the identified faultlines are examined - the nature of the island 'edge', the import for questions of island memory and identity of massive inward and outward movements of people, and the appropriation of island 'realness' by those for whom 'island' best functions as metaphor. A case is made for the excision of the latter from the purview of island studies. Despite apparent irreconcilability within island studies' emerging faultlines, it is argued that place theory does constitute a theoretical framing that can work for island studies. Following a brief overview of the faultlines that also exist within place studies, it is noted that the difference-respecting and identity focused nature of phenomenology of place is particularly apposite for island studies, and the paper concludes with a consideration of what a phenomenology of islands might look like.
\end{abstract}

Keywords: islands, island studies, nissology, place, phenomenology, faultlines

Copyright @ 2006 Institute of Island Studies, University of Prince Edward Island, Canada.

\section{The Ambiguous Construction of Islands: Towards a Coherent Nissology?}

Is a coherent theory of islandness possible? It is not clear that it is - indeed, disputation over this very point characterised the debate among leading island scholars that prefaced the establishment of this journal.

The case for the positive has been well put by McCall and Baldacchino (among others). McCall argues that, at a time of global threat to cultural and economic autonomy, "terrestrial states feel this threat of incorporation, even absorption, as a fact of life", but island states "not only feel this threat, but have it as an abiding and driving component of their history" (1996: 1; also Ledwell 2002: 3). From this point of strategic vantage "the next millennium is proposed as an 'Island Millennium' and Nissology is proposed as a rhetorical, sub-altern discourse for Islanders as well as for understanding islands in their stewardship of two thirds of the resources of the planet" (1996: 1). Similarly, Baldacchino argues that there is "much scope for unpacking what is meant by islandness" (2004a: 272) and that, the great diversity among islands notwithstanding, "island(ers) have a sufficient 
commonality to warrant looking at them comparatively, justifying a systematic 'island studies’ perspective” (2005a: 247; see also Anon., 1993: 1).

There are reasons why we would want there to be a coherent theory of islands. Darwin and Wallace laid the foundations for our understanding of evolutionary processes through studies specific to islands, and island biogeography has remained paradigmatic within ecological and evolutionary science (Clark, 2004a; Quammen, 1996; McArthur \& Wilson, 1967). Margaret Mead's foundational contribution to anthropology took place in the context of field research carried out in the islands of the Pacific. Ten percent of the world's population live on islands, nearly a quarter of all sovereign states are islands, and islands have taken the lead in the development of innovative forms of governance (Felt, 2003; Stratford, 2006a; 2006b), environmental management, and in the development of alternative energy technologies.

Perhaps, though, as 'islophiles' we will ourselves to pursue in vain the alluringly unattainable. Perhaps Hache’s blunt observation is apposite:

"Whether islands have anything in common besides their watery surroundings, and whether they are a useful model for reflection in the field of social sciences, are matters that have been hotly debated for some years. The extreme diversity of island situations has, of course, been the main stumbling block, as islands show a vast variety of geographical, social, cultural, political, or economic conditions, and a great multiplicity in the combination of these elements” (Hache, 1998: 35).

There are very many unresolved - perhaps unresolvable - faultlines within island studies. Even the question of what constitutes an island is not conclusively settled, and what constitutes a small island is a particularly contested issue. Whatever islandness is, it seems likely to be quite different for islands that are unambiguously small as against those that are not; for tropical islands as against cold or temperate ones; for islands primarily inhabited by aboriginal people as against islands now dominated by immigrant peoples who have settled within the last two to three centuries; for continental islands as against oceanic ones; for resource-rich as against resource-poor islands; for urbanised versus arcadian versus wild islands.

Contestation over such basic points of definition is just the beginning. Most definitions stress the hard-edged condition of island boundaries, but there is much debate over the nature and meaning of the island edge, and the extent to which such boundaries are actually hard edged. There is disagreement about the extent to which islandness can survive the dynamism of rapid population change in the wake of globalization, with island identities intrinsic to long-standing community ties displaced by the coming of wealthy recreational, tourist, or otherwise transitory populations, as well as part-time holiday home or twilight-of-life retirement residents. Similar unresolved issues of island identity stem from the linking of islands to mainlands by bridges and causeways (Baglole \& Weale, 1974; Baldacchino, 2004c; Royle, 1999; Royle et al., 1990; Weale, 1991). There is also the question of whether 'islandness' is even a condition to be desired. Baldacchino points out that "islands have occupied such a powerful place in modern Western imagination that 
they lend themselves to sophisticated fantasy and mythology. Paradises, but also Gulags, are generally islands" (2005a: 247-248). Whilst islophiles tend to be critical of the 'island as paradise, island as prison' bifurcation, along with "other paradigms [that] reveal themselves as continental and therefore partial and unsuited to diagnose 'islandness"” (Baldacchino, 2005a: 269), this dichotomy segues into the question of whether islands have anything to offer the rest of the world, and here, too, there is an absence of consensus.

Perhaps the most contested faultline within island studies is whether islands are characterised by vulnerability or resilience; whether they are victims of change, economically dependent, and at the mercy of unscrupulous neo-colonial manipulation, or whether they are uniquely resourceful in the face of such threats. Many island scholars enthusiastically talk up the capacity of islands to lead by example in the generation of resolutions to intractable global problems, whilst for those who are disinclined to accord legitimacy to island studies, islands are irrelevant backwaters within a dynamically integrated age. This seems to be the point, for example, of D.H. Lawrence's much-read story, The Man Who Loved Islands (1955): "The love of islands, the story maintains, is a neurotic condition. They are not so much islands as 'I'lands', where the inflated self smothers and obliterates all other forms of life" (Nicolson, 2002: 344). Further, for Lawrence "the healthy state is social... and islands represent a withdrawal from the mainstream where in some ways it is our duty to remain" (ibid.: 345). For those who hold such views, the island can even serve as a metaphor for backwardness and irrelevance (McCall, 1996: 3), as well as anti-social self-indulgence. In fact, within island studies, the very question of the island as metaphor is problematic. Is 'islandness' to do with a generalizable condition of physical isolation or a state of personal disconnection (a robust and tenaciously familiar metaphor and literary trope)? Or is it to do with the stuff of real geographical entities that more or less accord with one of those contested definitions of an island as a physical reality?

It seems very daunting: but a coherent, ready-to-hand theoretical basis in which island studies can lodge does exist. This will be espoused via a consideration of three of the nissological faultlines delineated above.

\section{Faultline 1 - The Contested Status of the Edge}

The notion of the edge is central to constructions of islandness, and islanders are more aware of and more confronted by the fact of boundaries than are most peoples - and the smaller the island the more this is so. Prince Edward Island's Harry Baglole, once wrote to me:

"The key feature of islands is of course the shoreline - the fixed but ever shifting perimeter ... Those who live inside this shoreline have a powerful sense of community - of communal home - dictated by geography. An island is a fundamental particle - an act of God, not a construct of man [sic], or of man's wars or of man’s politics” (2003; see also Weale, 2002: 1). 
Much island scholarship similarly emphasises the hard and emphatic edge of the island boundary, that "natural delimiter" (McCall, 1994: 3), the shoreline. "For island dwellers, the omnipresence of the sea intensifies the feeling of being cut off from the rest of the world", writes Péron: "the maritime boundary surrounding it is always there, solid, totalising and domineering” (2004: 300); whilst for Bonnemaison, “an island is defined by its shore. It is first and foremost a break and dive into the ocean, a dive that can be idyllic or dramatic” (cited in Penot \& Agnew, 1998: 255).

Those who stress the hard-edgedness of the shoreline also tend to emphasise the contribution such a heightened sense of physical containment makes to the construction of an island identity. Beem, writing in the context of the Maine islands, notes that, "in its watery isolation, every island determines a state of mind, a consciousness of limits that is not as sensible in the middle of a continent... Experience is circumscribed on an island, contained" (1992: 86). Similarly, Weale argues that "the most radical and deeply rooted concern of many Islanders has to do with what we might describe as the "islandness" of their identity, both as individuals and as a community" (1991: 81), for "there are polar people, coastal people, and people of the forests. In each case the nature of the community - its mythology, imagination, its very soul - has been sculpted by its geographical circumstances” (1991: 82).

The strong sense of island identity stemming from the sharpness of that wave-lined boundary is often said to consist in the community-defining bond of a shared sense of isolation that generates "a unique sense of difference to other populations" (Anderson, 2003: 48; also Faris, 1999: 25). Islophiles tend to extol this sense of insularity; to see it as a source of islander resilience and versatility, and a state of existence to be cherished. The isolation of islands, in Holm's view, answers an important need of the human psyche: "islands are necessary for us to be able to think about what is true at the bottom of our own character; we need to reduce the world for a while, to count it and understand it” (Holm, 2000: 11-12; also Deakin, 2000: 17).

In fact, paradigms of hard-edgedness and a consequent insularity are no longer much in favour within island studies, though the tendency seems to be less outright repudiation of them than a significant augmentation of the complexity with which we construct our understanding of islands. Terrell has argued that "islands are more varied, diverse, and complicated places than commonly believed", and that "isolation is not a defining characteristic of island life; to the contrary, it could be argued that islanders are generally more aware of, and in touch with, the worldwide web of human intercourse than others may be” (Terrell, 2004: 11; also Clark, 2004a: 288).

Most of the literature arguing against concepts of islands as essentially hard-edged and insular takes the view that the mobile, fluid, or permeable boundary - a "shifting liminality" (Beer, 2003: 33) - is a liberated zone; a site of possibility. For the editor of the Island Journal, islands are "excruciatingly pinioned between the global and the particular" (Anon. 1994: 1; also Baldacchino, 2005a: 248). Dening writes of the beach as a transit point that guarantees enrichment within islands (1980: 31), whilst for Ledwell, "the shoreline is a place of uncertainty and instability" (2002: 4) and, thus, a site "where things 
happen that could not happen anywhere else" (2002: 10). For Anderson, "the periphery represents the space between exclusion and inclusion, discrimination and acceptance, the known and the unknown... [it is] the space between the past and the future, utopia and hell, reality and the imagination" (2003: 47; also Edmond \& Smith, 2003: 2). So edges are 'edgy'. They attract the unconventional and the creative, and much might happen there.

Notwithstanding the appearance of hard boundaries and insularity, and its conduciveness to a strong sense of identity within islands, appearances deceive. Connectedness describes the island condition better than isolation, whilst that apparently emphatic boundary is the most permeable of membranes, 'wafer-thin' in Nicolson's view (2002: 140). Islands must trade if they are to overcome the constraints of a small or non-existent hinterland; and the smaller they are, the more this is the case (Baldacchino, 2004c: 99-100; 2005b: 35). Gillis argues that it was ever so; that "there is no culture in the world that can be said to be fixed and bounded, separate from other cultures" (2004: 118), though Beer sees the invention of the aeroplane as the decisive event in rendering island boundaries illusory (1990; also 1989: 21; 2003: 33). And as it is with culture, so it is with biophysical processes. McKibben (1989) argues that the by-products of human industry have so comprehensively penetrated natural processes that the earth's very atmosphere is, in part, artefact; thus, "we only think we escape to islands; we forget the wind, which blows spores and ashes from all over the planet to keep us company" (Holm, 2000: 74). A similar inter-planetary connectedness, and in a more benign sense, comes from a realization that the geological processes that manifest in islands continue beneath the sea, linking island to island, island to continent (Holm, 2000: 12; Nelson, 1991: 115-144; Waterston, 1998: 273).

It may even be that, rather than constituting movement-constraining barriers, island boundaries invite transgression; inspire restlessness; demand to be breached; impel islanders "to explore and even to escape into the unknown" (Anderson, 2003: 47). Perhaps the island edge is more than just permeable; perhaps it is actually the portal to roads and sea-trails fanning out to other (is)lands, a natural bridge to the world beyond. That, indeed, is the much-cited thesis of Hau'ofa (1993), for whom the ocean is the medium that links the Pacific islands into a vibrant field of communication. Drawing on Hau'ofa, and noting that "islands facilitate cultural exchange", Ellis argues that "navigation among islands continues to enable the rich networks of cultural and economic exchange that define the Pacific" (1998: 52). In place of "the perception of ocean as a vast empty space in which separate islands hang suspended", she sees inter-island space as alive with relational meaning, such that "no island is an island" (Ellis, 1998: 55; also Dening, 1980: 31-32; Edmond \& Smith, 2003: 2-9).

But, it can be asked, if 'no island is an island', what is there left for islands? If pushed too far, the answer must surely be: nothing at all.

\section{Faultline 2 - Comings, Goings, Stayings: Are Islands ‘Tenacious’?}

Perhaps the entities that we call islands are dissolving into a terrain-denying mesh of global information networks, a trend accompanied by an unprecedented transit of people. If 
so, is it not likely that island memory will vanish as the last intermediate-term resident swings away on the global roundabout? Where, in this brave new world, is the historical specificity to accord an island an identity, to establish it as this island and no other? Of course, a cultural blending of this sort is precisely what Hau'ofa and Ellis do not describe; they rather look to a regional cultural interchange that is enriching and nuanced. But surely the persistence of identity can only stand so much inward and outward movement of people; only so much absorption of invasive continental and off-island cultural influences - even if, as McCall reminds us, "migration is a major preoccupation of island states, either as emigration or immigration” (1994: 4). The consensus to date suggests that, despite dwindling remoteness and an end, in most cases, to seamless historical continuity, island identities have remained remarkably tenacious. "It is possible to bridge islands", Stratford observes, "but this may not render them something other than islands" (2006a: 274). Dening seems to say that a state of peripatetic island-hopping is almost the island condition, and that this is an exuberant activity wherein "each new intruder finds a freedom it never had in its old environments" (1980: 32). In the mix of the old and the new, island identities shift - they are endlessly remade, but enough remains constant for the island to persist.

This seems similar to the more policy-focussed position articulated by Baldacchino, who calls for "a respect for the dialectic of islands: roots and routes - which does not suggest defensive mono-culturalism. Rather, one is contemplating here an openness to diversity and pluralism, with minimal social class and status barriers and tensions" (2005b: 37). That is fine for comings, but what of leavings? “[T]he real challenge', says Baldacchino, "is not to prevent the mobile and able from leaving but to learn how eventually to tap their new skills for local purposes” (2005b: 37-38). One can only agree. Islanders do leave, and as often as not it is with a 'good riddance' on their lips; a sense of escape. Young and talented people leave because the island is deemed to offer an insufficiency of employment opportunity or recreational stimulation. My own island, Tasmania, is a case in point, and to my mind the tragedy is not that the young and the talented leave but that they may never find a reason to come back, or to make the sort of constructive contribution to island life from afar that Baldacchino envisages. On some islands the exodus is not even confined to the young, but may consist of older people with few of the skills demanded for success in the times in which we live (e.g. Royle, 2001: 88-96). This is the case with impoverished islands on which resources have been exhausted and ecological services irreparably despoiled; that are, perhaps, already depopulated to the point of non-viability; or perhaps they are overpopulated beyond the limits of sustainability, such that the export of population overflow is critical to survival. 'In the place I'm from you don't have much room', writes Jamaica Kincaid, "You have the sea. If you step on the sea you sink. The only thing the sea can do is take you away" (Bonetti, 1992; also Srebrnik, 1998: 160). Gillis makes much of the 'flight from entrapment' factor. Of the Scottish island of Colonsay, he reports: “[T]he mainland was forever on [the islanders'] minds, and... they imagined Colonsay not as a place of eternal return, but as somewhere at the end of time, living its last days” (Gillis, 2004: 155).

This, though, is very far from the perspective of Bonnemaison - which may mean nothing other than that Gillis and Bonnemaison are writing about very different islands existing in 
different planetary quadrants. Bonnemaison's Melanesian islands are sites of powerful primary attachments - though, like Dening, Bonnemaison locates these attachments in routes of movement: "identity is reproduced and reacquired in each generation through journeying and circulating within the areas of alliance and shared identity” (1985: 61).

For whatever reason, islanders leave, some with joy in their soul, some to evermore lament their alienation from a lost island home. And they are replaced by - and often displaced by - immigrants from elsewhere, often wealthier people seeking scapes of romantic isolation, and innocent of the cultural disruption that their coming entails, or at least represents. The process has been described as one of island gentrification (Clark, 2004b), and island writings abound with descriptions of the process and its impacts. Different perceptions of what is good for the island can lead to sustained conflict between incomers and residents of longer standing. For example, newly arrived retirees may "become staunch conservationists of the islescapes" and "resist developments favoured by less affluent locals” (Gillis, 2004: 156). The mere act of buying up island real estate, especially on the coast, can open a wound. Gillis writes (of the Sea Islands of the Carolinas) of "city folk" who bought land "with no real intention of living there" in order to get an island address on their stationery (2004: 165). Yet, there are movements of people which do not involve anything as emphatic as migration and whose comings and goings nonetheless threaten island tenacity. Mass tourism can have a similar impact, and as globalization renders destinations closer and more alike, and tourists fan across the globe in determined quest of the different and the remote, islands become favoured destinations. "Islands are now awash with seasonal sojourners”, notes Gillis (2004: 147); whilst Putz, writing of the Maine islands, gives this graphic summation:

"Older New Englanders will recall what Cape Cod was like 40 years ago, and Nantucket 30 years ago... All of these places have become very different from what they were. Among other things, these places used to be different kinds of places, unique places, not only with different kinds of geography and natural history, but also different kinds of heritage, uses of the English language, and patterns of interaction. By simple observation we understand that a pandemic kind of phenomenon happens because of recreational development. All these places are becoming more and more alike” (Putz, 1993: 53).

Is it too simple to observe that, the longer a community of people lives on an island, and the smaller the island, the stronger the sense of island identity, and of identification with the island? A civic community, Putnam (1992) reminds us, is bound together by relations of reciprocity and cooperation, and the trust in which such relations lodge accretes extremely slowly. On islands, the absence of relationships of trust and reciprocity may correlate with high levels of defeat- and despair-sourced emigration. Of Newfoundland (and its non-island jurisdictional partner, Labrador), Blackmore writes that "the length of time you spend in a place as an integrated member of its social fabric is an integral part of one's sense of belonging", and he identifies the need for "a network that is strong enough to give each person in the community a sense of having a 'right' to be there because they have earned that right through tenure” (Blackmore, 2003: 347). 
When Dening spins his images of insouciant inter-island voyagers, he clearly has all lifeforms in mind, not just humans. Several island scholars have reminded us of the links between island cultural diversity and island biodiversity (Clark, 2004a; DeLoughrey, 2004; Nunn, 2003; 2004; Tsai \& Clark, 2003; Tsai, 2003). In modern times, very many islands have experienced massive changes to native biota - DeLoughrey refers to this as 'the creolization and hybridity of biotic transplants' (2004: 299) - and impairment of ecological processes. The making-over of natural landscapes and biophysical processes in this way also poses a significant challenge to island identity. Writing of the Pacific islands, Nunn argues that 'there is abundant evidence that environmental changes of extraneous causation forced island peoples to alter a whole range of lifestyle options' (2003: 226), a view of nature-culture relations on islands that gives much more agency to environmental factors than do most considerations of island cultures written within a cultural studies framework. Works in the latter tradition tend to stress a cultural 'creolization' arising from the fluidity of global economic processes. Bongie, for instance, describes the transformations that he labels 'creolization' as “the entering into complex new relations of formerly isolated peoples under the sign of our ever more interdependent world economy" (1998: 7). In such a view of the motors of change, there would seem to be little scope for agency for the natural world. This explanation also seems to conduce to a pessimistic view of the resilience of island identities. For Gillis it is not even a proposition up for contest, for we live in a time when "physical islands retreat to the margins of history and geography" (2004: 165).

In terms of how to make sense of comings and goings, and of questions relating to the tenacity of island identities, much remains in dispute. Perhaps the clubbiness of island studies has militated against a sharpening of these differences, though biases stemming from the particular island contexts in which various scholars work and the discipline b(i)ases from which they proceed seem also to be important. For example, scholars whose 'patch' is the Caribbean tend to be suspicious of island scholarship that regards identity questions as central to the enterprise, because on racially charged islands identity politics are likely to be exclusionary and inflammatory. And natural scientists tend to take a somewhat different view of the culture-nature interface than do island-focused scholars working within cultural and literary studies paradigms, for the latter find notions of extreme flux more exciting than threatening. They also exhibit an understandable tendency to see the reality of islands as of less interest and import than the 'virtual' status of the island as metaphor.

\section{Faultline 3 - Rescuing the Real: Metaphor and the 'Hard Stuff' of Islands}

When Gillis consigns the island as a physical entity to the "margins of history and geography" he nevertheless sees a key role for islands in a "consciousness of ourselves and the world around us", wherein they "loom large" (2004: 165; also 2003; Polack 1998: 217). The metaphoric deployment of 'island' is, in fact, so enduring, all-pervading and commonplace that a case could reasonably be made for it as the central metaphor within western discourse. As Gillis writes, "western culture not only thinks about islands, but thinks with them" (2004: 1). 
And it is not as if 'island' has a single metaphorical connotation. Islands may be "quaint bastions of conformity and antique tradition, savage gardens of sexual delight, archetypes of human adaptation, social backwaters, impoverished stepchildren of colonial empires, and distant outposts of mercantile civilization" (Terrell, 2004: 5). As a 'category of the mind', the island's first and obvious application is to any segment of a continental landmass characterised by isolation and remoteness. "Islands are everywhere", writes Terrell, "not just out there in the deep blue sea" (2004: 7). Almost as ubiquitous is the deployment of 'island' as a metaphor for paradise, especially lost paradises of romantic yearning. Island metaphors may also be used to connote loss, especially of innocence, and a concomitant pathological condition of isolation and anti-sociality (Gabilondo, 1998: 88; McCall, 1996: 3-4). 'Lost garden of earthly delights' constructions are most common in 'marooned on a desert island' tales. These trace right back to the modern origins of literature in Defoe's Robinson Crusoe, though the oppositions of paradise and prison are often present in the same literary construction - as they are in Robinson Crusoe.

One prominent metaphor based around the figure of the heroically resourceful castaway links the island trope to ideological discourses of radical individualism, wherein the uniquely gifted and courageous individual rises above the constraints imposed by the mediocrity of the many (Beer, 1989: 16). But the island abstraction can also connote the precise opposite, serving as "a metaphor for a lost relationship between individual and community" (ibid.: 13). In the former deployment 'island' is an idea that becomes fixed as conservative, because the "contained and bounded self" (Polack, 1998: 218) of the superindividual who rises above society leads straight to history-is-wrought-by-a-few-great-men ideologies. Such a trope "privileges the individual over the collective, and denies the possibility of radical change" (ibid.). There are related metaphors that similarly function in a politically conservative way. One is the island as fortress, heroically protecting the pure and the noble from an ambience of threat and corruption (Waterston, 1998: 268). An alternative version reverses the meaning, and the island becomes a symbol for concentrated evil instead (Gabilondo, 1998: 88). Prison and quarantine islands are often used to this metaphoric effect. Another conservative metaphor is the nation as island. For conceptual credibility (the argument runs) the nation requires the reality of sharp and largely impervious boundaries, and thus "relies upon the cultural idea of the island" (Beer, 1989: 21). Polack notes a deployment of the same island metaphor in a slightly different way: "an island's boundaries provide the sort of fixed limits that make it a perfect microcosm of... national concerns" that are "less easily containable or comprehensible in other locations" (1998: 217). This may be a benign or a malign use of the island trope. In its relation to the nation of which it is part, my own island serves as a psychological sink into which the fears, self-loathings and insecurities of the larger nation are displaced.

The metaphor of the island as human individual also connects with metaphors of masculinity. "In the poetic identification of self with the island", Ledwell observes, "the masculinist western tradition has often stated or implied that individual identity and individuation require separation... In this formulation, each man is an island, despite Donne's assertions to the contrary” (Ledwell, 2002: 13). Through that man-against-nature and man-against-society heroism the island metaphor is wedded not just to conservatism, 
but to masculinity - but, further complicating the gendered usage of 'island' as metaphor, Beer has noted that it can also connote female! "Early in the nineteenth century", she notes, "Byron mockingly noted how, for the shipwrecked hero Don Juan, the maiden Haidee comes with the island, hardly to be distinguished from it; there, like the land, to receive, serve and succour incoming man” (Beer, 1989: 13).

Note, though, that the metaphor remains negative, denoting states and cultural attitudes that need to change. Most scholars interested in the metaphoric uses to which 'island' are put identify constructions of island that are negative, suggesting obsolescence, hideboundedness or structures of chronic injustice. Islandness is a dysfunctional state. In part this is because much interest in the island as metaphor is contained within paradigms of critical scholarship that seek to reveal and denounce the way 'post-colonialism' is perpetuated in obscure and subtle ways. The island itself is seen to be a post-colonial trope, one traceable to Eurocentric assumptions of dominance, and only recently challenged by those with a capacity to see past the screens and obfuscations. Furthermore, those constructions of islandness that stress identity, uniqueness and home are seen to partake of the persistence of post-colonialism, being wedded to outmoded values that take no cognizance of a postmodern fluidity in which endless change rather than enduring identities is the signature, and, thus, to be part of the problem rather than the solution. Insofar as they target subtle structures of dominance, those who take this position believe that they stand against such totalising processes as global economics, claiming to speak instead for a multiplicity of voices in a global anti-system characterised by fracture and impermanence.

It is true that structures of colonialism remain, and these are cultural/attitudinal, economic and political (Royle, 2001: 137-167). But much of the politics of island as metaphor may be wrong-headed. There is no necessary link between an identity-driven politics along the lines envisaged by many island writers and an exclusionary brutalism. There may be times when a politics of place identity conjoins with an illiberal politics of exclusion, but that requires other factors to be potently at play. What is far more typical, especially where island identity is concerned, is that an identity politics emerges from a desire to defend difference against the totalising trends within globalization. Writing of globalization and its implications for island studies, Clark notes: "the tendencies of globalization to level borders and reduce insularity entails the paving of heterogeneity and the expansion of homogeneity, as the rate of extinction of natural species and cultural systems outstrips the rate of speciation and cultural differentiation" (2004a: 289). Identity politics within islands, then, opposes the persistence of colonial structures (under the guise of globalization) and takes the side of autonomy and cultural diversity. To emphasise communal ties of identity is to set in place a progressive case for defending or promoting conditions in which autonomy, justice and dignity are possible. Even writings that engage with the nuts and bolts of institutional arrangements tend to assume, as an underlying values sub-text, the right of peoples - island peoples in this case - to speak for themselves, and to lead autonomous, self-directing lives (for example, Bartmann \& Milne, 1996; Lowenthal, 1988: yellow coded, 5-6). 
This is not only a discourse of resistance. Prominent within islands scholarship are bold claims concerning the situational capacity of islands to be global leaders in the face of emergent challenges. McCall (1996) has already been instanced in this regard; whilst, well over a decade ago, an Island Journal editorialist could observe that "each island... in some way has something to teach us about how life is lived when our island earth is a very small place" (Anon., 1992: 1). More expansively, Clark notes that, "to the extent that globalization involves transgression, relational displacement and levelling of boundaries in all their permeability and complexity, and to the extent islands underscore boundaries, island studies should provide an especially fruitful approach to the study of globalization processes and their consequences” (2004a: 291). The challenges faced by islanders are also thought to engender resourcefulness and resilience. These will manifest in strategies to resist identity-threatening processes of economic globalization, and the generation of imaginative developmental alternatives (Baldacchino 2005b).

Sustainability is one intractable problem area in which islands could, through exemplary practice, take the lead in the production of global solutions, as highlighted in the 2004 Kinmen Declaration (also Stratford, 2003; 2006a). At Macquarie University in Sydney, Australia, Hayward and others have developed a model and a website to give practical impetus to these visions (Hayward, 2005a), based upon the premises that the maintenance of biodiversity through preservation of habitat and the maintenance of cultural diversity through preservation of living cultural practices are non-negotiable principles of sustainability, and that from such specificity more generally applicable insights can be developed (Hayward, 2005b). Baldacchino's summation gets the practical promise of islands perfectly:

"[G]lobalization both standardises and homogenises, as well as highlights and invigorates, local initiatives and identities... The ability to source unique features or processes from specific islands, connect them to similar ones on other islands, and then analyse the implications of such links, presents promising and rewarding opportunities... not only are [islands] endowed with their own holistic and total environment; but each small fragment is a precious repository of attributes, of relevance to the rest, as well as to the species and the planet as a whole. Island studies grapples with uncovering the patterning of uniformity in a sea of revealing diversity, as well as with revealing the diversity persisting in an age of encroaching uniformity, the age of the fifth mass extinction since the origins of life on Earth” (2004b: 279).

Given such an agenda, proclamations of the death of the real island, and assertions that it is time to turn instead to the abstractions of metaphor, strike one as not only misplaced, but downright bizarre.

There is, though, an even stronger reason why island studies should look sceptically upon literary and cultural studies perspectives that dismiss the physicality of islands whilst promoting the relevance of metaphorical abstractions. There is a 1983 paper by the environmental philosopher, Mary Midgley, entitled 'Duties Concerning Islands'. One might expect such a text to have much to say about the nature of islands and islandness. It is certainly a tightly argued work of ecological ethics - but there is not a single observation 
in this paper about islands, or of any individual island. So powerful is the metaphorical idea of the island that it can be deployed in the absence of even the slightest reference to the reality of islands. Those who live real lives on islands are entitled to resent this. If the appropriation of an exotic island locale for works of literature that simply exploit that locale without genuinely engaging with it should be revealed as the persistence of a colonial cast of mind, so are islanders entitled to view all promotions of metaphorical senses of islands as acts of post-colonial appropriation. What they are being told is that the reality of their lives is of no account - or, at least, of less account than mere abstractions of the appropriatory mind. Island metaphors not only wrongly represent the politics of island identity as conservative, then; they also render irrelevant the realness of island lives. Such metaphors were not, after all, generated by islanders. They are continental, as well as colonial, constructions. I am at one with Holm: "without the weight of things, metaphors turn vapid, sour, empty, fly off into space and connect with nothing” (2000: 4).

Of course, it would be futile to stand against the continued use of such a robust metaphorical signifier. And given its literary and cultural prominence, it is well that there are those who wish to investigate it. It is just that I do not believe that they fit within the purview of nissological investigation, which should, rather, concern itself with the reality of islands and how it is for islands and islanders in the times that are here and that are emerging. That - given how dauntingly the complexities and faultlines present - should suffice.

There is one important manner in which metaphorical senses of islandness are the appropriate substance of island studies. This is when metaphoric transcriptions of islands rebound upon real islands and influence life there. Polack comes superbly to our assistance here. "There needs to be a greater awareness, she writes, "of the political implications of the figurations of our islands", and in this context she is particularly insightful in her assessment of "the nexus between the island and the solitary subject" (1998: 228). She notes (2002) that narratives of leaving, so prominent within metaphor-focused writings on islands, affirm the radical individuality that conduces to conservatism and market-centred worldviews, whereas the much less common homecoming trope affirms sociality and island collectivities. Her revisionist reading of this metaphor links specifically to discourses of defence and resistance:

"The feelings of isolation sometimes experienced by those who live on islands are primarily the result of the practical and metaphorical effects of the networks of global capitalism, not the physical boundedness of their islands. It is these networks that have helped to make islands the trope for individualist rather than collectivist notions” (Polack, 1998: 229).

Thus, islands should become "havens for the collective... continually interrogating the privileging of the relationship between the isolated individual and the bounded physical space” (ibid.). It is a most apposite observation of the politics of the island metaphor, and the way such metaphors complexly interact with the anti-colonialist agenda of island identity politics. 


\section{Theories of Place}

Having only looked at three of the faultlines within island studies. the picture that emerges is one of considerable variation in perspective, including the articulation of positions that may prove mutually exclusive, but that have not, to date, been recognised as immutably oppositional. The prospects for a coherent nissology seem, on the face of it, to be bleak. Why, then, do so many people desire to make sense of islands; why so many declared islophiles? Because islands - real islands, real geographical entities - attract affection, loyalty, identification. And what do you get when you take a bounded geographical entity and add an investment of human attachment, loyalty and meaning? You get the phenomenon known as 'place'. Islands are places - special places, paradigmatic places, topographies of meaning in which the qualities that construct place are dramatically distilled. In the quotes from island scholars hitherto deployed, the word 'place' regularly appears. 'Identity Through Place' and 'Special Places, 'Specially Wanted' are sub-heads from earlier cited papers by Bonnemaison (1985: 30), and McCall (1996: 1) respectively. And Baldacchino observes that "small islands are special because their 'geographical precision' facilitates a (unique) sense of place” (2005b: 35). Carol Shields beautifully articulates the heightened sense of place to which islandness conduces:

"Children born on [small] islands differ from Elsewhere children in that they are knowing of each rock and fencepost of their homeplace, of every field-corner and doorway, every spit of sand and beach pebble... [T]hey are able to look out across the widewater and observe the wonder and diversity of our earth-home. May it ever be so...” (Shields, 2004: 428).

Those who have sounded the knell over the physical island also tend to pronounce the passing of place. "Identity, once associated with location", writes Gillis, "has slipped its territorial moorings to become transnational" (2004: 147). But we have already argued for an excising of metaphorical deployments of islands from the purview of nissology, and just as we noted that "the juggernaut of globalization advancing inexorably over the planet, drawing all into one world of trade, one world of society, even, we fear, one world of culture" (McCall, 1996: 1) is the factor that has given the greatest fillip to island studies, so, too, has it been the major driving force behind a revived intellectual interest in place. What puzzles me most about the present state of island studies is that the latter proceeds with so little acknowledgement of what is now a vast theoretical literature on the nature of place and place attachment.

'Place' is an idea whose time has come. Within cultural/human geography, where 'place' has always been a key framing concept (albeit one viewed somewhat unproblematically), and within philosophy and cultural studies, the 1990s has seen a flourishing of academic course development and learned exposition focused upon the idea of 'place'. 'Place', we now know, is not unproblematic, but a complex, ideologically-coded idea, one that can lend support to conservative appeals to nationalism and communal insularity (often disguised as retreat-from-the-state appeals to local self-reliance), and one that, more significantly in my view, can serve as a mobilising principle for critiquing dysfunctional 
aspects of the global economy, and for structuring political opposition thereto. We have, now, cogent theories of place that are Marxist (Harvey, 2000; Massey, 1994), feminist (Duncan, 1996; Griffin, 1995; hooks, 1995), body-focused - in the sense of body as place (Duncan, 1996; hooks, 1990; Irigaray, 1993; Nast \& Pile, 1998), post-structuralist (Duncan \& Ley, 1993; Keith \& Pile, 1993; Smith, 1997), 'virtual' (Rheingold, 2000; Wark 1994; Wilson 2006), post-colonial (Agnew \& Duncan 1990; Keith \& Pile, 1993; Lefebvre, 1991), environmentalist (Cameron, 2003; Jacobs, 1995; Norton \& Hannon, 1997; Sagoff, 1993), ethicist (Malpas, 1999; Sack, 1997), and phenomenological (Augé, 1995; Buttimer \& Seamon, 1980; Relph, 1976; Seamon, 2005; Seamon \& Mugerauer, 2000; Tuan, 1977). Each parts company with the others at certain key points, but only occasionally is the one mutually exclusive of the other in the way that 'virtual' and phenomenological perspectives most certainly are. It will be apparent already that the faultlines within place theory closely resemble those emerging within island studies.

Theorists of place tend to differ most over how far the concept can be pushed. Those who are comfortable with globalising trends - with cultural globalising trends, in any case seek to free 'place' from 'ground': by making the body the primary site of 'place', or interpreting 'place' in terms of processes of flux and change, or to see it primarily as an 'event', rather than to interpret it in terms of its tenacities and continuities (Escobar, 2001; Massey, 1994). In such views, 'place’ tends to become another globally transportable commodity - just as Gillis argues islands have now become.

Others insist upon the centrality of 'hard' place - the geographic terrain of attachment. In his pioneering work on place and place attachment, Relph identifies what he believes to be a psycho-social need for assured roots; for the emotional anchor that a conception of 'coming from' provides. "A deep relationship with place”, he writes, "is as necessary as close relationships with people; without such relationships human existence is bereft of much of its significance” (Relph, 1976: 41). To be 'displaced', then - to be without any tie to 'home' - is a pathological human condition. And 'homeness' mandates deep, ongoing conversation with place, a 'dance of being' evocatively captured in Seamon's (1980) notion of "place-ballet", wherein unfolds a rich and particular human and natural history, one that privileges the transmission of place-specific myth, story, and vernacular technologies. A culture's embeddedness within a biotic community and the biophysical processes that have helped construct it is both a significant cultural asset and a prominent element within local identity (Norton \& Hannon, 1997), whilst 'places acquire much of their permanence as well as much of their distinctive character from the collective activities of people who dwell there, who shape the land through their activities, and who build institutions and social relationships within a bounded domain’ (Harvey, 1996: 310). It seems unnecessary to spell out the many nissological resonances here.

The 'permanence' in Harvey's observation is important. Place - as geographical terrain only has integrity if it retains a certain configuration through time. He also writes of place as 'the site of collective memory'. The tenacity of place may require that human-induced change occurs at a measured pace. In order that cultural place meanings can accrue (and these are not necessarily reducible to a single uncontested meaning, nor is the introduction of new narratives into the mix precluded as historical events come and go), there must also 
be a capacity to layer up stories, so that a potent vernacular culture (or cultures) can exist and persist, welding past to present and ensuring a seamless passage of time. There is, then, a vertical or temporal axis to place, as well as the obvious horizontal plane of space.

The integrity of place can be threatened on both axes - by brutal 'makings-over' of physical place that pay scant heed to historical or communal place meanings; and on the vertical axis when the thread of story and the seamless progression of time is snapped. The greatest threat to the integrity of place, on both axes, stems from the technological intrusiveness of dynamic global capital, intrusions that conduce to a loss of diversity and particularity. By engendering an unprecedented mobility of people such processes weaken the identity of places to the point where they not only look alike, but feel alike and offer the same bland possibilities for experience. They also provoke movements of resistance. Harvey writes of a "militant particularism" that invokes "vernacular traditions and icons of place" and "reanimates the bond between the environmental and the social" as "a basis for a politics of resistance" (1996: 306).

Given its focus upon experientially-derived identity and culture-nature symbiosis, the politics of local place that emerges from the phenomenological tradition seems best suited to the construction of a coherent theory for the special places that islands constitute, and for accommodation of the emergent faultlines within island studies. As 'a philosophy or theory of the unique [phenomenology] is interested in what is essentially not replaceable' (van Manen, 1997: 7); thus, phenomenological investigation lays stress upon vernacular constructions of meaning and their attendant technologies, beliefs, value codes and myth structures via a process of multi-sensorial receptivity to that-which-would-be-known, an openness that collapses the critical distance between subject and object, insisting that the two flow into each other. The most persistent criticism of place phenomenology is that it homogenises place, seeing it as reducible to a single meaning, and ignoring structures of power and exploitation that radically change the meanings with which place is imbued as one moves between groups, classes, genders and generations. Some place phenomenology does homogenize place, but most see the construction of place meaning as arising from a perpetual dialogue between the physicality of place and the interactions of people with it, and there is nothing intrinsic to this process that mandates one 'essential' place meaning.

In its stress upon the particularity of identity and experience, phenomenology of place makes common cause with the central concerns of island studies. "Today", writes Péron, "it would seem that nothing any longer distinguishes an island from a section of a contiguous mainland, where this exists. Roads, houses and communal facilities may have nothing distinctive about them" (2004: 328). But islands can survive as unique places, Péron argues, for "against the background of rapidly increasing personal mobility and globalization of the world economy, the island can be considered the quintessential physical place” (2004: 334). 


\section{Conclusion: A Phenomenology of Islands?}

If islands do remain special places, it is because the characteristics that endow space with the shared meanings that transform them into place may be more pronounced, better articulated, and more effectively defended on islands than is usually the case elsewhere. This can be acknowledged whilst still recognising the reality of Massey's "geometries of power" and that, accordingly, there may not be a single integrated meaning of island place, and that there will be those for whom the experience of island living is displacement; a sense of entrapment and opportunity denied.

Island meanings, divergent or convergent, emerge from a deeply visceral lived experience. They are phenomenologically generated and articulated. Books about particular islands written for a popular rather than an academic readership will sometimes move beyond the particular into general observations about 'islandness' (e.g. Clarke, 2001; Holm, 2000; Nicolson, 2002). Others will stay with their own island, sometimes offering tantalising asides to suggest that they could, if they chose, reflect generally upon islandness. But in almost all cases the island is a fully nuanced, complex and articulated character rather than a mere uni-dimensional backdrop (e.g. Blackburn, 1997; Crumley, 1994; Nelson, 1991; Souhami, 2001). In their a-theoretical expositions upon the nature of a particular island place, these writers are unselfconsciously proceeding phenomenologically. This is the approach to one's subject that, freed of the presumptions of theory, one naturally adopts.

Though islands may be considered a special focus of place studies, an almost paradigmatic one in which qualities are heightened, their essence distilled, and their meanings sharpened, this does not amount to a purpose-built nissology; it does not arise intrinsically from an engagement with islands specifically. Rather, it is yet another continentallyderived epistemological paradigm, and on this account it is likely that it will not be regarded as satisfactory by many islophiles; not in the long term, anyway. But I would submit that, precisely because it can accommodate faultlines of intractable difference, place phenomenology does work as a coherent theoretical framing for island studies - and that it does, then, demonstrate that the faith of many islophiles in nissological possibility is not misplaced.

\section{Acknowledgements}

The first section of this paper has benefited greatly from discussions with my friend and colleague, Andrew Harwood.

\section{References}

Agnew, J. \& Duncan, J., eds. (1990) The Power of Place, Boston MA, Unwin Hyman.

Anderson, M-L. (2003) ‘Norfolk Island: Pacific Periphery’, Island, No. 92, pp. 47-53. 
Augé, M. (1995) Non-Places: An Introduction to an Anthropology of Supermodernity, London, Verso.

Anon. (1992) untitled editorial, Island Journal, Maine, Island Institute, No. 9, p.1.

Anon. (1993) ““All Land is One Land under the Sea...”, Island Journal, Maine, Island Institute, No. 10, pp. 1-2.

Anon. (1994) ‘A Question of Scale’, Island Journal, Maine, Island Institute, No. 11, p. 1.

Baglole, H. (2003) personal communication, 2 June.

Baglole, H. \& Weale, D. (1974) Cornelius Howatt: Superstar, Charlottetown PEI, Williams \& Crue.

Baldacchino, G. (2004a) 'Editorial Introduction', Tijdschrift voor Economische en Sociale Geografie, Vol. 95, No. 3, pp. 269-271.

Baldacchino, G. (2004b) 'The Coming of Age of Island Studies', Tijdschrift voor Economische en Sociale Geografie, Vol. 95, No. 3, pp. 272-283.

Baldacchino, G. (2004c) "The Impact of Bridges and Other "Fixed Links" on Island Communities: When Small Islands Are Connected to Mainlands', in K.J. Lee \& H-M. Tsai, eds., Islands of the World VIII, Changing Islands - Changing Worlds: Proceedings (1), Kinmen, Taiwan \& International Small Islands Studies Association, pp. 99-110.

Baldacchino, G. (2005a) 'Islands - Objects of Representation', Geografiska Annaler, Vol. 87 B, No. 4, pp. 247-251.

Baldacchino, G. (2005b) 'The Contribution of 'Social Capital' to Economic Growth: Lessons from Island Jurisdictions’, The Round Table, Vol. 94, No. 1, pp. 31-46.

Bartmann, B. \& Milne, D. (1996) 'The Power of Jurisdiction: Provincehood and Other Models', symposium paper presented at: Maritime Union: Is it a Good Idea for PEI?, Charlottetown PEI, Institute of Island Studies, University of Prince Edward Island, pp. 3135.

Beem, E.A. (1992) 'Casco Bay Morning', Island Journal, Maine, Island Institute, No. 9, 86-87.

Beer, G. (1989) 'Discourses of the Island' in F. Amrine, ed., Literature and Science as Modes of Expression, Dordrecht, Kluwer Academic, pp. 1-27.

Beer, G. (1990) 'The Island and the Aeroplane: The Case of Virginia Woolf' in H.K. Bhabha, ed., Nation and Narration, London, Routledge, pp. 265-290. 
Beer, G. (2003) 'Island Bounds' in R. Edmond \& V. Smith, eds., Islands in History and Representation, London, Routledge, pp. 32-42.

Blackburn, J. (1997) The Emperor's Last Island: A Journey to St. Helena, London, Vintage.

Blackmore, G.C. (2003) Sense of Place: Loss and the Newfoundland and Labrador Spirit, Report presented to the Royal Commission on Renewing and Strengthening Our Place in Canada, www.gov.nl.ca/publicat/royalcomm/research/blackmore.pdf

Bonetti, K. (1992) 'An Interview with Jamaica Kincaid', The Missouri Review, Vol. 15, No. 2, www.missourireview.com/index.php?genre=Interviews\&title=An+Interview + with+Jamaic $\underline{\mathrm{a}+\text { Kincaid }}$

Bonnemaison, J. (1985) 'The Tree and the Canoe: Roots and Mobility in Vanuatu Societies’, Pacific Viewpoint, Vol. 26, No. 1, pp. 30-62.

Bongie, C. (1998) Islands and Exiles: The Creole Identities of Post/Colonial Literature, Stanford CA, Stanford University Press.

Buttimer, A. \& Seamon, D., eds. (1980) The Human Experience of Space and Place, New York, St. Martin’s Press.

Cameron, J., ed. (2003) Changing Places: Re-imagining Australia, Double Bay NSW, Longueville.

Clark, E. (2004a) 'The Ballad Dance of the Faeroese: Island Biocultural Geography in an Age of Globalization', Tijdschrift voor Economische en Sociale Geografie, Vol. 95, No. 3, pp. 284-297.

Clark, E (2004b) 'Island Gentrification', paper presented at Islands of the World VIII, Changing Islands - Changing Worlds, Kinmen Island, Taiwan, 4 November.

Clarke, T. (2001), Searching for Crusoe: A Journey among the Last Real Islands, London, Little Brown.

Crumley, J. (1994), Among Islands, Edinburgh, Mainstream.

Deakin, R. (2000) Waterlog, London, Vintage.

DeLoughrey, E. (2004) 'Island Ecologies and Caribbean Literatures', Tijdschrift voor Economische en Sociale Geografie, Vol. 95, No. 3, pp. 298-310.

Dening, G. (1980) Islands and Beaches: Discourse on a Silent Land, Marquesas 17741880, Melbourne, Melbourne University Press. 
Duncan, J \& Ley, D., eds. (1993) Place/Culture/Representation, New York, Routledge.

Duncan, N., ed. (1996) Bodyspace: Destabilizing Geographies of Gender and Sexuality, London, Routledge.

Edmond, R. \& Smith, V. (2003) 'Editors' Introduction' in R. Edmond \& V. Smith eds., Islands in History and Representation, London, Routledge, pp. 1-18.

Ellis, J. (1998), 'Literary Cartographies in Oceania' in L. Brinklow, F. Ledwell \& J. Ledwell, eds., Message in a Bottle: The Literature of Small Islands, Charlottetown PEI, Institute of Island Studies, University of Prince Edward Island, pp. 51-64.

Escobar, A. (2001) 'Culture Sits in Places: Reflections on Globalism and Subaltern Strategies of Localization’, Political Geography, Vol. 20, No. 2, pp. 139-174.

Faris, R.W. (1999) 'Unto Themselves: Insularity and Democracy’, Masters thesis, Chapel Hill NC, Department of Sociology, University of North Carolina.

Felt, L.F. (2003) Small, Isolated and Successful: Lessons from Small, Isolated Societies of the North Atlantic, Report presented to the Royal Commission on Renewing and Strengthening Our Place in Canada, www.gov.nl.ca/publicat/royalcomm/research/Felt.pdf

Gabilondo, P. (1998) “"A Second Creation”: in Search of the Island of the Colourblind’ in L. Brinklow, F. Ledwell \& J. Ledwell, eds., Message in a Bottle: The Literature of Small Islands, Charlottetown PEI, Institute of Island Studies, University of Prince Edward Island, pp. 85-100.

Gillis, J. (2003) 'Taking History Offshore: Atlantic Islands in European Minds' in R. Edmond \& V. Smith, eds., Islands in History and Representation, London, Routledge, pp. 19-31.

Gillis, J. (2004) Islands of the Mind: How the Human Imagination Created the Atlantic World, New York, Palgrave Macmillan.

Griffin, S. (1995) The Eros of Everyday Life: Essays on Ecology, Gender and Society, New York, Doubleday.

Hache, J.-D. (1998) 'Toward a Political Approach to the Island Question' in G. Baldacchino \& R. Greenwood, eds., Competing Strategies of Socio-Economic Development for Small Islands, Charlottetown PEI, Institute of Island Studies, University of Prince Edward Island, pp. 31-68.

Harvey, D. (1996) Justice, Nature and the Geography of Difference, Malden MA, Blackwell. 
Harvey, D. (2000) Spaces of Hope, Berkeley CA, University of California Press.

Hau'ofa, E. (1993) Our Sea of Islands, Suva, Fiji, School of Social and Economic Development, University of South Pacific.

Hayward, P. (2005a) 'Culturally Engaged Research and Facilitation: Active Development Projects with Small Island Cultures', paper presented at $1^{\text {st }}$ International Small Island Cultures Conference, Kagoshima Centre for the Pacific Islands, Japan, www.sicri.org

Hayward, P. (2005b) 'Local and Global Heritage in Island Cultures', public lecture given at University of Prince Edward Island, Charlottetown (PEI), 15 June, www.sicri.org

Holm, B. (2000) Eccentric Islands: Travels Real and Imaginary, Minneapolis MN, Milkweed.

hooks, b. (1990) Yearning: Race, Gender and Cultural Politics, Boston MA, South End Press.

Irigaray, L. (1993) An Ethics of Sexual Difference, Ithaca NY, Cornell University Press.

Jacobs, M. (1995) Sustainability and Socialism, London, Socialist Environment and Resources Association.

Keith, M. \& Pile, S., eds. (1993) Place and the Politics of Identity, London, Routledge.

Kinmen Declaration, The (2004), International Studies of Small Islands Association, Islands VIII International Conference General Meeting, November, www.giee.ntnu.edu.tw/island/

Lawrence, D.H. (1955) The Complete Short Stories of D.H. Lawrence, Vol. III, London, Heinemann Ltd.

Ledwell, J. (2002) 'Afraid of Heights, not Edges: Representations of the Shoreline in Recent Prince Edward Island Poetry and Visual Art', paper presented at Islands of the World VII, Charlottetown PEI, University of Prince Edward Island, www.bisd.hollandc.pe.ca/islands7/

Lefebvre, H. (1991) The Production of Space, Oxford, Blackwell.

Lowenthal, D. (1988) 'Island Self-Reliance or Expert Delusion?' in Islands 88: Proceedings of the $2^{\text {nd }}$ Conference of Islands of the World, University of Tasmania, Hobart (TAS), yellow coding.

McArthur, R.H. \& Wilson, E.O. (1967) The Theory of Island Biogeography, Princeton NJ, Princeton University Press. 
McCall, G. (1994) 'Nissology: A Proposal for Consideration', Journal of the Pacific Society, Vol. 17, Nos. 2-3, pp. 1-8.

McCall, G. (1996) 'Nissology; A Debate and Discourse from Below', www.southpacific.arts.unsw.edu.au/resourcenissology.htm

McKibben, B. (1989) The End of Nature, New York, Random House.

Malpas, J.E. (1999) Place and Experience: A Philosophical Topography, Cambridge, Cambridge University Press.

Massey, D. (1994) Space, Place and Gender, Minneapolis MN, University of Minnesota Press.

Midgley, M. (1983) 'Duties Concerning Islands' in R. Elliot \& A. Gare, eds., Environmental Philosophy, St. Lucia, University of Queensland Press, pp. 166-181.

Nast, H. \& Pile, S., eds. (1998) Places through the Body, London, Routledge.

Nelson, R. (1991) The Island Within, New York, Random House.

Nicholson, A. (2002) Sea Room: An Island Life, London, HarperCollins.

Norton, B.G. \& Hannon, B. (1997) 'Environmental Values: A Place-Based Approach, Environmental Ethics, Vol. 19, No. 3, pp. 227-246.

Nunn, P.D. (2003) 'Nature-Society Interactions in the Pacific Islands' Geografiska Annaler, Vol. 85 B, No. 4, pp. 219-229.

Nunn, P.D. (2004) 'Through a Mist on the Ocean: Human Understanding of Island Environments', Tijdschrift voor Economische en Sociale Geografie, Vol. 95, No. 3, pp. 311-325.

Penot, J. \& Agnew, J. (1998) 'How Cultural Boundaries Limit Intellectual Horizons: Reflections on the Untimely Death of Joel Bonnemaison (1947-1997)', Environment and Planning D: Society and Space, Vol. 16, No. 3, pp. 253-256.

Péron, F. (2004) 'The Contemporary Lure of the Island', Tijdschrift voor Economische en Sociale Geografie, Vol. 95, No. 3, pp. 326-339.

Polack, F. (1998) 'Writing and Rewriting the Island: Tasmania, Politics and Contemporary Island Fiction' in L. Brinklow, F. Ledwell \& J. Ledwell, eds., Message in a Bottle: The Literature of Small Islands, Charlottetown PEI, Institute of Island Studies, University of Prince Edward Island, pp. 215-230. 
Polack, F. (2002) 'Always More to Imagine: The Literary Allure of Islands', paper presented at the North Atlantic Forum, Sydney NS, 13 October.

Putnam, R. (1992) Making Democracy Work: Civic Traditions in Modern Italy, Princeton NJ, Princeton University Press.

Putz, G. (1993) “"The More Things Change, the More They Get the Same...”: Why Recreational Culture Kills Island Life', Island Journal, Maine, Island Institute, No. 10, pp. 53-55.

Quammen, D. (1996) The Song of the Dodo: Island Biogeography in an Age of Extinctions, New York, Touchstone.

Relph, E. (1976) Place and Placelessness, London, Pion.

Rheingold, H. (2000), The Virtual Community: Homesteading on the Electronic Frontier, Cambridge MA, MIT Press.

Royle, S.A. (1999) 'Bridging the Gap: Prince Edward Island and the Confederation Bridge’, British Journal of Canadian Studies, Vol. 14, No. 2, pp. 242-255.

Royle, S.A. (2001) A Geography of Islands: Small Island Insularity, London, Routledge.

Royle, S.A., Robinson, J. \& Smith, B.L. (1990) 'Fixed Link in the Western Isles: The Barra-Watersay Causeway’, Scottish Geographical Magazine, No. 106, pp. 117-120.

Sack, R. (1997) Homo Geographicus, Baltimore MD, John Hopkins University Press.

Sagoff, M. (1993) ‘Environmental Ethics: An Epitaph’, Resources, Spring, 2-7.

Seamon, D. (1980) 'Body-Subject, Time-Space Routines and Place Ballets' in A. Buttimer \& D. Seamon, eds., The Human Experience of Space and Place, London, Croom Helm, pp. 148-165.

Seamon, D. (2005) 'Phenomenology, Place, Environment, and Architecture', Environmental and Architectural Phenomenology Newsletter, No. 16. Available at: www.arch.ksu.edu/seamon/Seamon_reviewEAP.htm

Seamon, D. \& Mugerauer, R. (2000) 'Dwelling, Place and Environment: An Introduction' in D. Seamon \& R. Mugerauer, eds., Dwelling, Place and Environment: Towards a Phenomenology of Person and World, Malabar FL, Krieger, pp. 1-12.

Shields, C. (2004) Collected Stories, London, Fourth Estate. 
Smith, M. (1997) 'Against the Enclosure of the Ethical Commons: Radical Environmentalism as an "Ethics of Place”, Environmental Ethics, Vol. 19, No. 4, pp. 339354.

Souhami, D. (2001), Selkirk’s Island, London, Orion.

Srebrnik, P. (1998) “"The Meaning of an Island”: Paradoxical Space in Writing by Authors from the Caribbean' in L. Brinklow, F. Ledwell \& J. Ledwell, eds., Message in a Bottle: The Literature of Small Islands, Charlottetown PEI, Institute of Island Studies, University of Prince Edward Island, pp. 159-176.

Stratford, E. (2003) 'Flows and Boundaries: Small Island Discourses and the Challenge of Sustainability, Community and Local Environments’, Local Environment, Vol. 8, No. 5, pp. 495-499.

Stratford, E. (2006a) 'Technologies of Agency and Performance: Tasmania Together and the Constitution of Harmonious Island Identity’, Geoforum, Vol. 37, No. 2, pp. 273-286.

Stratford, E. (2006b) 'Isolation as a Resource in the Constitution of the New Tasmania: Some Thoughts on Subnational Island Status', paper presented at Senses of Place Conference, University of Tasmania, Hobart, Tasmania, April.

Terrell, J.E. (2004) 'Islands in the River of Time', Islands of the World VIII International Conference 'Changing Islands - Changing Worlds': Proceedings. Available at: www.giee.ntnu.edu.tw/island

Tsai, H.M. (2003) 'Island Biocultural Assemblages - the Case of Kinmen Island', Geografiska Annaler, Vol. 85 B, No. 4, pp. 209-218.

Tsai, H.M. \& Clark, E. (2003) 'Nature-Society Interactions on Islands', Geografiska Annaler, Vol. 85 B, No. 4, pp. 187-189.

Tuan, Y.-F. (1977) Space and Place: The Perspective of Experience, Minneapolis MN, University of Minnesota Press.

Van Manen, M. (1997) Researching Lived Experience: Human Science for an Action Sensitive Pedagogy, $2^{\text {nd }}$ edn, London ON, Althouse.

Wark, McK. (1994) Virtual Geography: Living with Global Media Events, Bloomington IN, Indiana University Press.

Waterston, E. (1998) 'The Iconography of Islands: Margaret Atwood and L.M. Montgomery' in L. Brinklow, F. Ledwell \& J. Ledwell, eds., Message in a Bottle: The Literature of Small Islands, Charlottetown PEI, Institute of Island Studies, University of Prince Edward Island, pp. 265-276. 
Weale, D. (1991) 'Islandness’, Island Journal, Maine, Island Institute, No. 8, pp. 81-82.

Weale, D. (2002) 'Here and Away', paper presented at the Islands of the World VII conference, Charlottetown PEI, University of Prince Edward Island. www.bisd.hollandc.pe.ca/islands7/

Wilson, S. (2006) 'Digital Communities/Locational Illusions: Representations of Place in Contemporary New Media Practice', paper presented at Senses of Place Conference, University of Tasmania, Hobart, Tasmania, April. 